ПРАКТИЧНІ ШЛЯХИ РЕАЛІЗАЦІЇ ТЕХНОЛОГІЇ ФОРМУВАННЯ ГОТОВНОСТІ СТУДЕНТІВ ЗВО ДО НАУКОВО-ДОСЛІДНИЦЬКОЇ ДІЯЛЬНОСТІ НА ЗАСАДАХ АКАДЕМІЧНОЇ ДОБРОЧЕСНОСТІ

\title{
PRACTICAL WAYS OF IMPLEMENTATION OF TECHNOLOGY IN FORMATION OF UNIVERSITY STUDENTS' WILLINGNESS TO CONDUCT SCIENTIFIC RESEARCH ON THE BASIS OF ACADEMIC INTEGRITY
}

\begin{abstract}
У статті презентується технологія формування готовності студентів університетів до науково-дослідницької діяльності на засадах академічної доброчесності. Аналізуються наукові підходи до визначення змісту поняття «академічна доброчесність» у сучасній світовій научі та розгляд у науковому дискурсі проблематики ії забезпечення у науково-дослідницькій діяльності. Звертається увага на недостатню вивченість прочесів формування академічної доброчесності студентів у ЗВО. Надається авторське визначення технологіі, що презентується. Зазначається, що реалізація технології фоормування готовності студентів до науководослідницької діяльності на засадах академічної доброчесності була організована $у$ навчальному процесі Харківського національного університету міського господарства імені О.М. Бекетова. Формування у студентів готовності до цього виду діяльності здійснювалося у прочесі викладання дисциплін суспільно-гуманітарного циклу, у межах яких закладалися основи понятійного апарату наукового дискурсу, дисциплін фрахового спрямування, що слугували основною базою для здійснення науково-дослідної діяльності студентів та дисциплін магістерської програми підготовки фрахівців, які виступали як тестовий цикл, що дає змогу констатувати рівень сорормованості готовності студентів. Надаються суттєві характеристики технології та наводяться особливості фрормування компонентів готовності студентів до науково-дослідницької діяльності на засадах академічної доброчесності: мотиваційно-рефрлексивного, когнітивно-комунікаційного, деонтологічного, організаційного та оцінно-результативного. Розкриваються різні аспекти впровадження технології на конкретних прикладах. Робиться висновок щодо ефективності впроваджених заходів і необхідності подальшого розроблення щодо виявлення особливостей упровадження зазначеної технології залежно від спеціальності та спеціалізації студентів.

Ключові слова: педагогічна технологія
\end{abstract} академічна доброчесність, науковий плагіат, науково-дослідна робота студентів.

The article represents the technology in formation of university students' willingness to conduct scientific research on the basis of academic integrity. New scientific approaches towards the defining the content of "academic integrity" notion have been analyzed as well as the researches of given issue and its support in scientific activities. Attention is paid to insufficient research of the processes of formation of academic integrity among university students. Author's definition of the presented technology has been given. It has been stated that the implementation of the technology in formation of university students' willingness to conduct scientific research on the basis of academic integrity has been organized in the learning process at O.M. Beketov National University of Urban Economy in Kharkiv. The formation of university students' willingness for such activities had been conducted during the process of teaching subjects of social and humanitarian cycle. Within these subjects the foundations of the conceptual apparatus of scientific discourse had been laid as well as within the subjects of professional orientation, which had served as the basis for research activities of students, and the subjects of the master's program of training specialists which had served as the test cycle that ensured the level of formation of students' willingness. The essential characteristics of technology have been given and the special features of forming the components of students' willingness to conduct scientific research activities on the basis of academic integrity have been presented: motivational-reflexive, cognitivecommunicative, deontological, organizational and evaluative-effective. Various aspects of technology implementation have been presented on specific examples. Conclusions have been drawn as for the effectiveness of the implemented measures and the need for further development to identify the features of the implementation of this technology depending on the specialty and academic programs of students.

Key words: educational technology, academic integrity, plagiarism in scientific writing, scientific research of students. університету міського господарства імені О.М. Бекетова
Постановка проблеми у загальному вигляді. У сучасному суспільстві існує підвищений попит на фрахівців, які спроможні оперативно вирішувати проблеми, реалізовувати творчі ідеї у кінцевому продукті діяльності, що затребуваний світовим ринком. Саме вищій освіті, що готує фрахівців такого рівня, належить значний науковий інтелектуально-творчий потенціал, здатний утілити людські продуктивні ресурси, що забезпечують прогрес розвитку суспільства. Вищу освіту слід розуміти й як особистісне надбання для виконання профресійної діяльності, тому що саме в процесі професійної підготовки у ЗВО важливим $є$ не лише оволодіння основами вибраної спеціальності, а й визначення можливих горизонтів власного особистісного та професійного розвитку. Професійній підготовці майбутніх фрахівців до вирішення принципово нових завдань сприяє науково-дослідна діяльність студентів, тобто опанування ними методології наукових досліджень для результативного пошуку вирішення проблемних ситуацій у професійній діяльності. Але під час фрормування готовності студентів до науково-дослідницької діяльності слід постійно пам'ятати, що академічна 
культура й академічна доброчесність $€$ невід'ємними складниками соціально відповідальної поведінки особистості протягом усього життя.

Аналіз останніх досліджень і публікацій. Проблематика забезпечення академічної доброчесності у науково-дослідницькій діяльності протягом останніх років $€$ актуальною у науковому дискурсі. Зміст поняття «академічна доброчесність» (academic integrity, academic honesty) проаналізовано у працях зарубіжних і вітчизняних науковців, таких як Т. Ґаллант, М. Рой, М. Гарфінкель, Л. Шлессельман, Дж. Бейлі, Р. Барбато, М. Дойчик, Ю. Малогулко, І. Тодорова, О. Семеног, Т. Іщенко та ін. Підсумовуючі наукові підходи до визначення світовими вченими цього поняття у ракурсі вищої освіти, О. Чумак під академічною доброчесністю розуміє «багатогранну категорію, яка визначає систему правових та морально-етичних принципів і правил під час здобуття вищої освіти та надання послуг із вищої освіти, які забезпечують високу якість отриманих навчальних та наукових результатів» [4, с. 9]. Поняття академічної доброчесності включає у себе такі цінності, як запобігання шахрайству, фральшуванню та плагіату; підтримка академічних стандартів; чесність і ретельність у дослідженнях та науковому видавництві [1, с. 9]. Науковці наполягають, що суть розв'язання проблеми академічної доброчесності полягає, насамперед, у світоглядно-ціннісній площині. Академічна доброчесність означає, що «в процесі навчання та дослідницької роботи студенти, викладачі та науковці повинні керуватися, передусім, принципами чесної праці та навчання, що є невід'ємним складником академічної культури та передумовою успішного розвитку суспільства» [3, с. 56].

Предметом уваги науковців $€$ також вивчення міжнародного досвіду забезпечення академічної чесності (Т. Лічман, О. Ковальчук, Л. Потапюк), аналіз поширених фрорм академічної недоброчесності та методи боротьбі 3 академічним плагіатом (О. Гайтан, А. Горошко, К. Зозуля, Т. Івахнюк, К. Поляк, О. Рижко, В. Сацик, Г. Ульянова), дослідження академічної доброчесності в контексті розвитку вищої освіти (Т. Добко, Т. Фінікова, А. Артюхов, Д. Сопова), упровадження принципів академічної доброчесності в освітньому та науковому середовищі (Ю. Гаруст, О. Вертеш-Гопак, О. Денисюк, Д. Задирака, В. Червоний) тощо. Огляд теоретичних підходів та результатів емпіричних досліджень академічного шахрайства здійснено $€$. Шмельовою. Ґрунтовним є також емпіричне дослідження проявів академічної недоброчесності і фрактів плагіату в американських коледжах, здійснене С. Блюм [5]. Процес фрормування академічної чесності в освітньому процесі в школі досліджували О. Крикова, С. Певко, О. Гужва та ін.

Виділення не вирішених раніше частин загальної проблеми. Слід зауважити, що, незва- жаючи на значну кількість наукових розвідок, здебільшого за межами уваги дослідників залишилися процеси фрормування академічної доброчесності студентів у ЗВО.

Мета стаття. Мета роботи полягає у презентації розробленої нами технології фрормування готовності студентів ЗВО до науково-дослідницької діяльності на засадах академічної доброчесності, розкритті суттєвих її характеристик та особливостей упровадження, визначенні її перспективних можливостей.

Виклад основного матеріалу. Формування готовності студентів до науково-дослідницької роботи є одним 3 актуальних напрямів розвитку освітнього процесу у ЗВО, і найважливішим при цьому є врахування принципів академічної доброчесності. Спираючись на проаналізовані наукові матеріали і власні висновки, ми розуміємо технологію фрормування готовності студентів до науководослідницької діяльності на засадах академічної доброчесності як сукупність взаємодії викладачів, спрямованої на становлення й розвиток особистості студента як майбутнього науковця та (або) фрахівця, який керується у власній діяльності принципами доброчесності, а також систему цілей, змісту, методів, фрорм, засобів, способів та прийомів навчання, видів контролю й корекції, що поетапно впроваджуються у навчальний процес 3ВО та гарантують досягнення кінцевого результату.

Межі статті не дають можливості надати детальну характеристику кожному з розроблених нами аспектів технології, зазначимо лише, що іï складниками було визначено описово-цільовий, що містить мету, завдання та попередню діагностику сорормованості готовності студентів до науково-дослідницької діяльності на засадах академічної доброчесності; наукознавчий, який установлює методологічні засади та головні принципи реалізації технології; процесуально-дієвий, що характеризує зміст реалізації технології, та оцінно-рефлексивний складник, який визначає критеріально-показниковий апарат дослідження та презентує його результати.

Практичні шляхи впровадження технології формування готовності студентів ЗВО до науководослідницької діяльності на засадах академічної доброчесності передбачали конструювання цілісного педагогічного процесу і були реалізовані у навчальному процесі Харківського національного університету міського господарства імені О.М. Бекетова.

Основними дисциплінами, у межах яких здійснювалася підготовка студентів до науководослідницької діяльності, було вибрано дисципліни суспільно-гуманітарного циклу, у межах яких закладалися основи понятійного апарату наукового дискурсу, структури різного виду наукових продуктів («Українська мова за професійним 
спрямуванням», «ноземна мова», «Основи права», «Основи наукового дослідження»), дисципліни фрахового спрямування (у нашому разі всі фрахові дисципліни були за спеціальністю «Архітектура»): «Історія архітектури, містобудування та мистецтва», «Архітектурне проектування» (курсова), «Архітектурне моделювання», «Основи районного планування», «Урбаністика») та дисципліни магістерської програми підготовки фрахівців за означеним профрілем («Комплексне архітектурне проєктування», «Комплексний проєкт будівлі громадського призначення» (курсова)), які виступали як тестовий цикл, що дає змогу констатувати певний рівень сорормованості готовності студентів до науково-дослідницької діяльності.

Реалізація розробленої нами технології передбачала фрормування певних компонентів готовності студентів ЗВО до науково-дослідницької діяльності на засадах академічної доброчесності. Першим кроком було фрормування мотиваційнорефрлексивного компоненту (мотивів творчого підходу до навчальної діяльності, виявлення наукової креативності, самостійного творення нового, відповідальності за наукові продукти). Результативним у цьому аспекті виявилося використання рефлексивних вправ щодо професійного саморозвитку, визначення місця наукового пізнання у майбутній профресійній діяльності, залучення студентів до аналізу результатів власної наукової діяльності, забезпечення «інфрормаційної насиченості» та «інформаційного комфорту» (можливість користування арсеналом добре організованих джерел інфрормації, зокрема вільним безкоштовним доступом до ресурсних баз видань Scopus та Web of Science) тощо. Отже, у студентів створювалося усвідомлення необхідності копіткої праці задля результативності діяльності. Ефективним мотиватором виявилося також усвідомлення студентами корисності власного наукового доробку для загальної наукової або комерційної теми.

Формування когнітивно-комунікаційного компоненту відбувалося у межах двох аспектів: впливу на когнітивно-пізнавальну сферу студентів щодо набуття знань і компетенцій науководослідницької діяльності та виявленні означених компетенцій у наукових та дослідницьких заходах або продуктах, до яких студенти мали можливість долучитися у позанавчальній діяльності. Так, наприклад, у межах викладання дисципліни «Українська мова за професійним спрямуванням» та «ноземна мова» досить велику увагу приділялося навчанню студентів створювати наукові тексти. Робота $з$ поняттєвим апаратом та тематичною проблематикою наукового дослідження організовувалася у межах викладання дисципліни «Основи наукового дослідження» та дисциплін фрахового спрямування. Під час вивчення дисципліни «Основи наукового дослідження», крім кла- сичної схеми підготовки студентів до написання курсової роботи, обов'язково акцентувалася увага на темі фрормування наукового мислення дослідника, оскільки для формування його компетенцій важливим $є$ розвиток особливого типу мислення, що спрямоване на розвиток і якісне перетворення суспільства в окремих його галузях. Із цією метою на заняттях використовувався банк кейсів із проблемами, що стосуються конкретної галузі й водночас $€$ важливими для суспільства, наукового підходу у вирішенні конкретної проблеми у цілому, зокрема якщо проблема виявляється на міжгалузевому рівні. При цьому орієнтувалися на усвідомлення студентами п'яти типів протиріч: протиріччя експерименту (протиріччя між двома або кількома дослідними даними); протиріччя між дослідом і теорією (фактом і узагальненням); протиріччя між старою і новою (менш і більш повною) теоріями; протиріччя між двома співіснуючими односторонніми теоріями; протиріччя між об'єктивними і суб'єктивними чинниками в конкретній системі [2, с. 88]. Варто зазначити, що ефективним для застосування на заняттях завжди вважався прийом візуалізації, який у сучасному навчанні якісно перетворений способом відеопрезентацій.

Для розвитку наукового мислення, необхідного у дослідницькій діяльності, широко використовувалися асоціативні методи наукового пошуку. Так, ефективними виявилися вправи на актуалізацію асоціативно-метафроричного мислення студентів (віднаходження логічного зв'язку між двома зовсім різними поняттями, що з'ясовувався у процесі асоціативного переходу). Для розвитку нешаблонного мислення використовувався прийом інтерпретації значення метафор у технічних термінах, при цьому звернемо увагу, що розширенню простору пошуку ідей сприяло застосування не однієї, а низки метафрор (гірлянди метафор): концентрованих гірлянд (по-різному виражають одне й те саме поняття); гірлянд послідовних метафрор (попередня метафора $€$ ключовим поняттям для утворення наступної). Прикладом такого метафоричного заміщення можна вважати оригінальні вправи 3 дисципліни «Урбаністика», у процесі яких студенти мали віднайти заміщення поняттям «точкова забудова», «локація», «середовище» (метафоричні форми: відірвані від спільноти, ціль збору, ріка однодумців).

У фрормуванні когнітивно-комунікативного компоненту велике значення надавалося організації комунікаційних можливостей наукового самовиявлення студентів, яке відбувалося у різних фрормах зовнішньої (позанавчальної) наукової діяльності, зокрема у конкурсних заходах (олімпіади, конкурси, гранти, стипендіальні програми тощо). Організація наукової взаємодії студентів із викладачами виявлялася передусім у залученні майбутніх фрахівців до науково-дослідної роботи кафедр. Результатами такої співпраці стали спільні наукові 
продукти викладачів і студентів: «Містобудівельні аспекти створення системи суспільного велопрокату у м. Харків», «Проблеми і шляхи вирішення транспортної інфрраструктури у плануванні сучасних міст», «Вплив фракторів зовнішнього середовища на обсяги перевезення пасажирів метрополітеном», «Екомісто - сучасне втілення технологій майбутнього» та ін. Розвиток готовності до науково-дослідницької діяльності студентів відбувався у межах заходів, спрямованих на усвідомлення важливості наукових компетенцій для подальшого фрахового самовиявлення. Так, взаємодія з роботодавцям у межах архітектурнодизайнерського конкурсу TILE AS STYLE на кращу розробку колекцій керамічної плитки спрямовувала студентів до якнайкращого виявлення власної готовності до наукових досліджень із метою отримання запрошення на перше робоче місце.

Формування деонтологічного компоненту відбувалося у межах викладання гуманітарних дисциплін. Наприклад, до змісту дисципліни «Українська мова за профресійним спрямуванням» було введено тему «Академічна доброчесність», що мало за мету ознайомлення студентів із проблемою недоброчесності, зокрема плагіату у різних сорерах життя, усвідомлення змісту понять «плагіат» та «академічний плагіат», визначення ролі процесів запобігання академічному плагіату й боротьби з ним в академічних середовищах. Перше завдання виконували шляхом представлення студентам видів плагіату у різних мистецьких галузях: кінематографрі, музиці. Окрім того, студенти мали змогу самі долучитися до пошуку плагіатних фрорм у творчості виконавців, зокрема після перегляду музичних добірок YouTube-каналу (http://dziga.meta.ua/5843777.video?pav=1).

Для усвідомлення понять, пов'язаних 3 академічною недоброчесністю, було створено презентацію, у змісті якої виокремлювалися види плагіату за західноєвропейською класифікацією, наприклад: CLON - дослівне копіювання чужої роботи; FIND-REPLACE - заміна ключових слів та фрраз зі збереженням основного змісту джерела; RECYCLE - значні запозичення з попередніх робіт самого автора без цитування, тобто само плагіат, та ін. Окрім того, студентів ознайомлювали з проблемою ненавмисного плагіату, який може бути результатом невміння науковця працювати з текстом. Розуміння зазначеного надавало можливість студентам усвідомлювати суспільні позиції щодо проблеми академічного плагіату, видів боротьби 3 ним та засобів його запобігання, пропонованих у межах академічних середовищ різних країн.

Ураховуючи те, що фрормування доброчесності тісно пов'язане зі знаннями студентів про інтелектуальну власність, у зміст дисципліни «Основи права» було введено модуль «Право інтелектуальної власності», у межах якого розглядалися питання об'єктів права інтелектуальної власності; правового захисту від недобросовісної конкуренції; захисту авторського права та суміжних прав. Корисною для студентів стала інформація про сервіси перевірки роботи на плагіат, зокрема Unplag - сервіс із перевірки робіт на плагіат, створений українськими розробниками у 2014 р. У межах ХНУМг імені О.М. Бекетова цей сервіс використовується як програма, що інтегрується 3 навчальною системою Moodle. На заняттях студенти мали можливість долучитися до навчальної перевірки наукових робіт на плагіат через зазначену систему. Кольорове виділення фррагментів тексту, який система визначала як неправомірно запозичений, ставало свідченням того, що жодна маніпуляція несамостійної роботи не буде прийнята до перевірки викладачем без попередньої перевірки в електронній програмі.

У фрормуванні організаційного компоненту готовності до науково-дослідницької діяльності передусім звертали увагу на ознайомлення студентів із тайм-менеджментом як здоров'язбережувальною технологією, яка допомагає здійснювати діяльність продуктивно та ефективно 3 найменшою кількістю витраченого часу. Для впливу на увагу використовували вправи на виявлення зайвого (наприклад, неправильно використаного терміна) у текстах наукового стилю, порушення логіки у вступі й висновках тощо. Ефективним як для розвитку уваги, так і для фрормування компетенції оформлення наукового тексту виявилися вправи на виявлення помилок в оформленні цитованих джерел. Окрім того, студентам давали можливість створити висловлювання за допомогою використання візуальних тренажерів різного виду: схем, презентацій, наочних приладів. Така підготовка до усної доповіді давала змогу поліпшити діяльність пам'яті.

Формування оцінно-результативного компоненту відбувалося упродовж усього експерименту. Для організації усвідомлення студентами рівня власної готовності до науково-дослідницької діяльності у межах навчальних занять було організовано рефрлексію діяльності через застосування прийомів незакінчених речень, планування наступної діяльності після аналізу результатів попередньої, створення інтелект-карти наукового пошуку за темою дослідження (курсова робота) тощо. Також студентів спонукали до регулярного аналізу просування у науковому пошуку, зокрема до аналізу виконаних завдань та часу, який було витрачено на це виконання.

Висновки. Таким чином, у процесі впровадження презентованої технології ефективними виявилися: проведення певного комплексу заходів, таких як мотивація студентів до наукового пізнання, самовиявлення у різних видах науково-дослідницької діяльності; підкреслення зв'язку змісту науково-дослідницької діяльності 
3 конкретними професійними завданнями за профрілем підготовки студентів; опанування знань, що дають цілісне уявлення про наукову діяльність, правил виконання науково-дослідних робіт і принципів академічної доброчесності; роз'яснення студентам цілей академічної сумлінності, причин та видів порушень, можливих наслідків і способів боротьби з ними; розвиток творчого підходу до навчальної діяльності, забезпечення відповідальності за наукові продукти тощо.

Перспективним напрямом подальших досліджень уважаємо виявлення особливостей упровадження технології формування готовності студентів 3 ВО до науково-дослідницької діяльності на засадах академічної доброчесності залежно від спеціальності та спеціалізації студентів.

\section{БІБЛІОГРАФІЧНИЙ СПИСОК:}

1. Академічна доброчесність: проблеми дотримання та пріоритети поширення серед молодих уче- них : колективна монографрія / за заг. ред. Н.Г. Сорокіної, А.Є. Артюхова, І.О. Дегтярьової. Дніпро : ДРІДУ НАДУ, 2017. 169 с.

2. Важинський C.E., Щербак T.I. Методика та організація наукових досліджень : навчальний посібник. Суми : СумДПУ імені А.С. Макаренка, 2016. 260 c.

3. Клименко О.В. Впровадження принципів академічної доброчесності в Національному медичному університеті імені О.О. Богомольця. Академічна доброчесність: виклики сучасності : збірник наукових есе учасників дистанційного етапу наукового стажування для освітян, м. Варшава, 09.09-21.09.2019). Варшава, 2019. С. 56-59.

4. Чумак О.В. Концепт категорії академічної доброчесності у вищій освіті. Теорія та методика управління освітою. 2017. № 2(20). URL: http://umo. edu.ua/images/content/nashi vydanya/metod upr osvit/v2_17/\%D0\%A7\%D1\%83\%D0\%BC\%D0\%B̄0\% 0\%BA.pdf.

5. Susan D. Blum. My Word!: Plagiarism and College Culture. Cornell University Press, 2009. 229 c. 